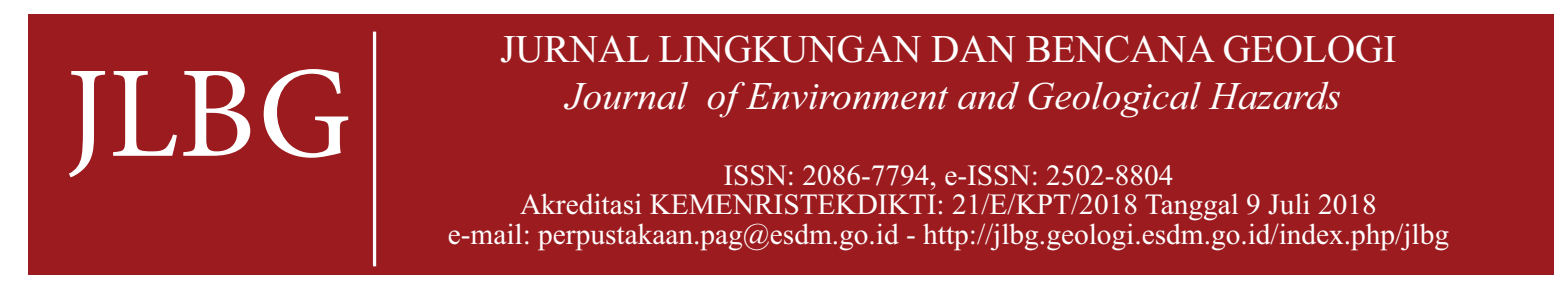

\title{
Perbandingan Nilai Hazard Kejadian Tsunami di Indonesia Berdasarkan Posisi Garis Khatulistiwa (Katalog Tsunami Indonesia 1802 - 2018)
}

\author{
Comparison of Tsunami Hazard Ratio in Indonesia \\ Based on Equator Position (BMKG Tsunami Catalog 1802 - 2018)
}

\author{
Samsul Anwar \\ Jurusan Statistika, Fakultas MIPA Universitas Syiah Kuala \\ Jln. Syech Abdurrauf, Kopelma Darussalam, Banda Aceh, 23111, Indonesia \\ e-mail: samsul.anwar@unsyiah.ac.id \\ naskah diterima 31 Januari 2020, selesai direvisi 20 April 2021, dan disetujui 30 April 2021
}

\begin{abstract}
ABSTRAK
Indonesia merupakan salah satu negara yang rawan terjadinya tsunami. Berdasarkan Katalog Tsunami BMKG, sepanjang tahun 1802 hingga 2018 telah terjadi 219 tsunami di Indonesia. Dengan mempelajari kejadian tsunami pada masa lalu berarti merupakan salah satu langkah mitigasi bencana dalam upaya meminimalisir kerugian yang disebabkan oleh tsunami pada masa yang akan datang. Tujuan penelitian ini adalah menghitung nilai hazard rasio kejadian tsunami berdasarkan lokasi kejadiannya relatif terhadap garis khatulistiwa. Model Cox Proportional Hazard (Cox $P H)$ menunjukkan bahwa tsunami di wilayah selatan garis khatulistiwa cenderung $50,5 \%$ lebih cepat terjadi dibandingkan dengan wilayah utara. Hal ini disebabkan karena wilayah selatan berpotensi lebih besar akan terjadinya kejadian tsunamigenik termasuk gempa bumi, erupsi gunungapi dan penyebab lainnya dari pada wilayah utara. Adanya zona subduksi aktif akibat pertemuan lempeng tektonik Indo-Australia dan Eurasia di wilayah selatan meningkatkan potensi terjadinya tsunamigenik di wilayah tersebut. Penelitian lebih lanjut diperlukan untuk menjelaskan hubungan antara garis khatulistiwa dengan kejadian tsunamigenik di Indonesia.
\end{abstract}

Kata kunci: garis khatulistiwa, hazard rasio, Indonesia, model cox $p h$, tsunami, tsunamigenik

\section{ABSTRACT}

Indonesia is a tsunami prone country. Based on the BMKG Tsunami Catalog, from 1802 to 2018 there were 219 tsunamis in Indonesia. By studying tsunami events in the past means as one disaster mitigation measures in an effort to minimize losses caused by tsunamis in the future. The objective of the study is to measure the tsunami hazard ratio based on its location relative to the equator position. Cox Proportional Hazard Model (Cox PH) showed that tsunamis in the southern area tended to happen 50.5\% faster compared to the northern area. This is because the southern region has greater potential for tsunamigenic events including earthquakes, volcanic eruptions and other causes than the northern region. The existence of an active subduction zone due to the confluence of Indo-Australian and Eurasian tectonic plates in the southern region increases the potential for tsunamigenic events in the region. Further research is necessarily needed to explain the relationship between the equator and tsunamigenic events in Indonesia.

Keywords: equator, hazard ratio, Indonesia, cox ph model, tsunami, tsunamigenic

\section{PENDAHULUAN}

Pada tahun 2018, Badan Meteorologi dan Geofisika (BMKG) menerbitkan buku mengenai katalog kejadian tsunami di Indonesia. Katalog tersebut berisikan data historis tsunami yang pernah terjadi di Indonesia dalam kurun waktu tahun 416 sampai dengan tahun 2017. Buku tersebut disusun sebagai salah satu implemen- 
tasi kegiatan pelayanan publik BMKG dalam hal mitigasi bencana gempa bumi dan tsunami di Indonesia yang menjadi salah satu tanggung jawab BMGK (BMKG, 2018). Data kejadian tsunami pada buku tersebut dibagi ke dalam 6 periode waktu yaitu sebelum tahun 1600 , antara 1600 - 1699, 1700 - 1799, 1800 - 1899, 1900 -1999, dan 2000 - 2017.

Menurut Setyonegoro (2011), tsunami adalah kumpulan gelombang air atau ombak yang disebabkan oleh perpindahan volume air dalam skala besar misalnya yang terjadi di lautan. Kecepatan rambat gelombang tsunami sangat tergantung pada kedalaman laut. Perambatan gelombang tsunami setelah guncangan akan lebih cepat pada laut dalam dan menjadi lebih lambat pada laut yang lebih dangkal (Fradin dan Fradin, 2008; Triatmodjo, 1999). Gelombang tsunami berbeda dengan ombak secara umumnya. Ombak hanya memindahkan air pada tingkat permukaan laut, sedangkan gelombang tsunami memindahkan air pada seluruh kolom dari permukaan hingga dasar laut yang bergerak ke segala arah (Sanjaya, 2018). Karena besarnya volume air dan energi yang dibawa, tsunami dapat menghancurkan wilayah pesisir sehingga menimbulkan banyak kerugian jiwa dan material.

Upaya mitigasi bencana diperlukan untuk meminimalisir kerugian yang disebabkan oleh kejadian tsunami, baik kerugian jiwa maupun material berupa infrastruktur di daerah yang berpotensi terkena dampak tsunami. Menurut Oktiari dan Manurung (2010), jumlah korban dapat dikurangi dengan menghitung potensi kerentanan tsunami sebagai sumber bencananya. Salah satu cara yang dapat dilakukan dalam mitigasi bencana tsunami adalah dengan mengestimasi waktu tiba gelombang tsunami terutama bagi daerah-daerah yang terancam tsunami (Hartanto, 2016). Dengan mengetahuinya, masyarakat atau pemerintah setempat dapat mempersiapkan diri terhadap bencana tersebut. Pacific Tsunami Warning Center (PTWC) merupakan sebuah lembaga yang bertugas untuk mengeluarkan peringatan dini tsunami (berupa daerah yang terkena tsunami serta waktu tiba gelombang tsunami) bagi negara-negara di kawasan pasifik termasuk Indonesia.

Upaya lain yang dapat dilakukan dalam mitigasi bencana tsunami adalah dengan mempelajari kejadian tsunami dari data historis. Data masa lalu dapat digunakan untuk mereduksi kerugian pada masa yang akan datang dengan mengidentifikasi tingkat hazard (bahaya) dari gempa bumi dan tsunami (Satake dan Atwater, 2007). Data BMKG menunjukkan bahwa jumlah kejadian tsunami di Indonesia sejak tahun 416 hingga 2017 adalah sebanyak 243 kali yang dihimpun dari berbagai sumber (BMKG, 2018). Data tersebut dapat digunakan dalam analisis hazard (bahaya) tsunami yang dilihat dari data durasi (interval) waktu antar kejadiannya. Melalui analisis tersebut dapat diketahui kecenderungan kejadian tsunami di Indonesia. Data lain dari National Oceanic and Atmospheric Administration (NOAA) menunjukkan bahwa secara keseluruhan paling sedikit telah terjadi 235 tsunami dalam 4 abad terakhir dan Indonesia merupakan salah satu negara yang paling rentan terhadap gempa bumi (Paris drr., 2007).

Kejadian gempa bumi sering dihubungkan dengan potensi tsunami (Setyonegoro, 2011). Gempa bumi merupakan salah satu faktor penting penyebab terjadinya tsunami terutama pada gempa bumi yang berpusat di laut. Salah satu bencana alam paling dahsyat yang terjadi dalam seabad terakhir adalah bencana tsunami yang terjadi di Aceh pada tanggal 26 Desember 2004 (Wang dan Liu, 2007). Tsunami tersebut disebabkan oleh sebuah gempa bumi besar di lepas pantai Aceh dengan magnitudo 9,3 (Younger drr., 2009). Beberapa penelitian lainnya menyatakan bahwa gempa bumi tersebut memiliki magnitudo antara 9,1 hingga 9,3 (Ito drr., 2016; Lay drr., 2005; Satake dan Atwater, 2007; Stein dan Okal, 2005; Subarya drr., 2006). Gempa bumi pada 26 Desember 2004 tersebut dikenal dengan nama gempa bumi SumateraAndaman (Lay drr., 2005; Løvholt drr., 2006). Gempa bumi Sumatera-Andaman menyebabkan terjadinya tsunami dengan puncak tertinggi 
Perbandingan Nilai Hazard Kejadian Tsunami di Indonesia Berdasarkan Posisi Garis Khatulistiwa (Katalog Tsunami Indonesia 1802 - 2018)

mencapai 51 meter (Paris drr., 2010). Jumlah korban bencana gempa bumi dan tsunami tahun 2004 diperkirakan sebanyak 230.000 jiwa yang berasal dari 14 negara yang terkena dampaknya (Paris drr., 2007).

Sejauh ini, gempa bumi di Indonesia sangat dikaitkan dengan letak geografis Indonesia yang berada di antara tiga lempeng tektonik dunia, yaitu Lempeng Indo-Australia, Eurasia dan Samudera Pasifik. Menurut Natawidjaja (2007), Lempeng Indo-Australia bergerak ke arah utara menun jam Lempeng Eurasia dengan kecepatan $50-70 \mathrm{~mm} /$ tahun di sepanjang palung laut Pulau Sumatera, Jawa, Bali dan Lombok. Hal ini menyebabkan wilayah tersebut memiliki potensi yang besar untuk terjadinya gempa bumi. Lebih rinci, penelitian dari Jatnika drr. (2016) menunjukkan bahwa pertemuan kedua lempeng tersebut memberikan pengaruh yang besar terhadap kondisi tektonik dan vulkanik di wilayah Sumatera bagian utara yang mengakibatkan terbentuknya deretan gunung api dan zona sesar yang terbentang sepanjang pulau Sumatera.

Menurut Rifai dan Pudja (2010), ada dua sumber gempa bumi tektonik di wilayah Sumatera yaitu pada zona subduksi di sepanjang Samudera Hindia dan pada zona-zona sepanjang sesar Sumatera di daratan. Hasil penelitian Lusiani drr. (2019) menunjukkan bahwa Aceh adalah wilayah yang paling terkena dampak tsunami pada 26 Desember 2004 memiliki tingkat seismisitas yang tinggi. Penelitian tersebut juga menunjukkan bahwa Aceh Singkil merupakan wilayah dengan tingkat resiko terjadinya gempa bumi yang paling besar untuk $M \geq 7$ dibandingkan dengan wilayah lainnya. Selain itu, penelitian dari Setyonegoro (2011) menunjukkan bahwa wilayah Sumatera bagian barat juga merupakan daerah tektonik aktif yang kerapkali menimbulkan bencana gempa bumi dan tsunami.

Selain di wilayah Sumatera, zona subduksi Sulawesi Utara juga merupakan kawasan tektonik yang sangat aktif. Seismisitas yang tinggi di wilayah tersebut disebabkan oleh zona sub- duksi Sulawesi Utara, zona subduksi lempeng laut Maluku dan sesar-sesar lokal yang ada di wilayah tersebut (Wahyu drr., 2018). Penelitian lain yang dilakukan oleh Nugraha drr. (2014) menyimpulkan bahwa wilayah sekitar Pulau Jawa, Bali dan NTB juga merupakan wilayah rawan bencana gempa bumi yang berpotensi mengakibatkan terjadinya tsunami. Di samping gempa bumi, erupsi gunungapi bawah laut, tanah longsor dan guncangan lainnya baik yang berada di atas maupun di bawah air memiliki potensi untuk menyebabkan tsunami (Setyonegoro, 2011).

Selain dikaitan dengan zona subduksi akibat pertemuan antarlempeng, kejadian tsunami juga menarik untuk dianalisis berdasarkan lokasi kejadiannya dilihat dari posisi garis khatulistiwa. Indonesia merupakan salah satu dari sebelas negara yang dilalui garis khatulistiwa (National Geographic, 2012). Menurut National Geographic (2011), garis khatulistiwa adalah garis imajiner sepanjang $40.075 \mathrm{~km}$ pada posisi lintang 0 derajat yang membelah bumi menjadi dua bagian yang sama yaitu bagian bumi utara yang berada di atas garis khatulistiwa hingga kutub utara bumi dan bagian bumi selatan yang berada di bawah garis khatulistiwa hingga kutub selatan bumi. Penelitian mengenai efek dari posisi belahan bumi (utara dan selatan) terhadap kejadian gempa bumi dan tsunami masih sangat jarang dilakukan. Meskipun tidak melakukan penelitian mengenai kaitan antara tsunami dengan garis khatulistiwa secara langsung, tapi Borrero drr. (2006) menyimpulkan bahwa penduduk pesisir Pulau Sumatera yang berada di selatan garis khatulistiwa berpotensi serius terpapar oleh kejadian tsunami.

Dengan demikian, penelitian ini bertujuan untuk membandingkan kejadian tsunami di wilayah Indonesia berdasarkan lokasi kejadiannya relatif terhadap garis khatulistiwa melalui analisis hazard tsunami. Zona subduksi di sekitar wilayah Sumatera bagian selatan, Jawa, Bali, NTB hingga Papua bagian selatan merupakan wilayah yang berada pada bagian belahan bumi selatan, sedangkan zona subduksi di sekitar 
wilayah Sumatera bagian barat laut, Sulawesi Utara, Halmahera hingga Papua bagian utara merupakan wilayah yang berada pada bagian belahan bumi utara. Perbandingan tersebut akan membantu menjawab apakah posisi bumi (utara dan selatan) memiliki pengaruh terhadap kejadian tsunami di Indonesia.

\section{METODE PENELITIAN}

Penelitian ini menggunakan data historis kejadian tsunami di Indonesia yang bersumber dari buku Katalog Tsunami Indonesia Tahun 416-2017 dengan jumlah sebanyak 243 kejadian (BMKG, 2018). Meskipun katalog tersebut memiliki data kejadian tsunami mulai dari 416, tetapi hanya data tsunami dari tahun 1802 hingga 2017 yang digunakan dan ditambah 2 kejadian pada tahun 2018 dengan jumlah total sebanyak 219 kejadian. Data yang dianalisis adalah data durasi waktu (dalam satuan bulan) antar kejadian tsunami yang berurutan di wilayah Indonesia berdasarkan lokasi kejadiannya (utara dan selatan garis khatulistiwa). Data kejadian tsunami sebelum tahun 1802 banyak yang tidak dicatat secara lengkap tanggal dan bulan kejadiannya, sehingga durasi waktu antar kejadian tsunami tidak dapat dihitung secara tepat. Beberapa kejadian tsunami yang dianalisis juga tidak dilengkapi dengan tanggal kejadiannya. Karena menggunakan skala waktu bulanan, kejadian tsunami tersebut diasumsikan berdistribusi secara uniform dengan tanggal 15 (tengah bulan) dipilih sebagai tanggal kejadiannya. Jumlah tsunami yang tidak dilengkapi dengan tanggal kejadiannya adalah sebanyak 11 kejadian atau sekitar 5,02\% dari total data yang digunakan.

Data durasi waktu antar kejadian tsunami dianalisis dengan menggunakan metode survival model Cox Proportional Hazard (Cox PH) (Kleinbaum dan Klein, 2012). Penggunaan model Cox PH dimaksudkan untuk menganalisis perbandingan nilai hazard (hazard ratio) kejadian tsunami di wilayah utara dan selatan garis khatulistiwa. Selain itu, juga dihitung nilai fungsi reliabilitas kejadian tsunami di kedua wilayah tersebut dengan menggunakan metode non-parametrik Kaplan-Meier (ReliaSoft Corporation, 2015). Lebih lanjut, perbandingan kurva reliabilitas pada kedua wilayah dianalisis dengan metode Log Rank test (Kleinbaum dan Klein, 2012). Ketiga analisis tersebut akan memberikan gambaran mengenai perbandingan kejadian tsunami di wilayah utara dan selatan garis khatulistiwa di Indonesia.

Pengolahan data menggunakan bantuan perangkat lunak Microsoft Excel dan $R$ versi 3.3.1 dengan package yang digunakan adalah survival dan geosphere. Ada 5 langkah analisis data yang dilakukan dalam penelitian ini. Pertama, menampilkan statistik deskriptif berupa nilai minimum, maksimum, rata-rata, median dan standar deviasi (SD) dari data durasi waktu antar kejadian tsunami di Indonesia berdasarkan lokasi kejadiannya relatif terhadap garis khatulistiwa. Kedua, membangun model Cox PH dengan lokasi kejadian tsunami (utara dan selatan garis khatulistiwa) sebagai variabel penjelas dan durasi waktu antar kejadian tsunami sebagai variabel respon. Ketiga, melakukan uji serentak, uji parsial dan pengujian asumsi $\mathrm{PH}$ terhadap model $\mathrm{Cox} \mathrm{PH}$ pada tingkat signifikansi $\alpha=0,05$. Keempat, menghitung nilai fungsi reliabilitas data durasi waktu antar kejadian tsunami berdasarkan lokasi kejadiannya dengan metode Kaplan-Meier dan membandingkan kurva reliabilitas dengan Log Rank test. Kelima, melakukan analisis dan interpretasi dari perbandingan hazard kejadian tsunami di Indonesia berdasarkan lokasi kejadiannya (utara dan selatan bumi) relatif terhadap garis khatulistiwa.

Analisis survival adalah metode statistika yang digunakan untuk menganalisis variabel respon berupa waktu sampai terjadinya sebuah kejadian atau peristiwa (Kleinbaum dan Klein, 2012). Kejadian tersebut dapat berupa kematian, kegagalan fungsi, kecelakaan, kerusakan atau kejadian lainnya. Data dalam analisis survival dapat berupa data tersensor maupun tidak tersensor. Data dikatakan tersensor apa- 
Perbandingan Nilai Hazard Kejadian Tsunami di Indonesia Berdasarkan Posisi Garis Khatulistiwa (Katalog Tsunami Indonesia 1802 - 2018)

bila waktu terjadinya sebuah peristiwa tidak diketahui secara lengkap waktu awal atau akhir kejadiannya. Sedangkan data tidak tersensor adalah data lengkap yang diketahui waktu awal dan akhir kejadiannya. Secara umum ada dua fungsi penting dalam analisis survival yaitu fungsi reliabilitas dan fungsi hazard. Menurut Kleinbaum dan Klein (2012), fungsi reliabilitas menggambarkan peluang sebuah observasi tetap bertahan/berfungsi setelah waktu $t$ dengan syarat bahwa observasi tersebut telah bertahan sampai dengan waktu $t$. Sedangkan fungsi hazard menjelaskan laju kegagalan seketika dari sebuah observasi yang telah memiliki masa hidup $t$ satuan waktu (Zacks, 1992).

Ada beberapa model dalam analisis survival, salah satunya adalah model Cox Proportional Hazard (Cox PH). Menurut Kleinbaum dan Klein (2012), model Cox PH merupakan model multivariat yang digunakan untuk menganalisis hubungan antara variabel respon $(T)$ dengan variabel penjelasnya $\left(\boldsymbol{X}=\left(X_{1}, X_{2}, \ldots, X_{n}\right)\right)$. Model Cox $P H$ diberikan pada Persamaan (1):

$$
h(t, X)=h_{0}(t) \exp \left(\sum_{i=1}^{p} \beta_{i} X_{i}\right)
$$

di mana $h_{0}(t)$ merupakan fungsi baseline dan $\beta_{1}$ merupakan koefisien model Cox $P H$. Nilai hazard ratio $(H R)$ diestimasi dengan menggunakan Persamaan (2):

$$
\widehat{H R}=\exp \left(\sum_{i=1}^{p} \widehat{\beta}_{1}\left(X_{i}^{*}-X_{i}\right)\right.
$$

Di mana $X^{*}=\left(X_{1}^{*}, X_{2}^{*}, \ldots, X_{p}^{*}\right)$ adalah variabel penjelas dari kelompok pertama dan dan $X=\left(X_{p}, X_{2}, \ldots, X_{p}\right)$ adalah variabel penjelas dari kelompok kedua. Salah satu asumsi penting dalam model Cox $P H$ adalah $H R$ harus bernilai konstan terhadap waktu (proportional hazard atau $P H$ ). Asumsi tersebut menunjukkan bahwa nilai $H R$ tidak dipengaruhi oleh unsur waktu $t$.

Dalam model Cox $P H$, terdapat tiga pengujian statistik yang harus dilakukan yaitu pengujian secara serentak melalui statistik Likelihood Ra- tio (LR) test, pengujian secara parsial melalui statistik Wald dan pengujian asumsi Proportional Hazard (PH) melalui statistik Chi Square. Dua pengujian pertama dikatakan signifikan bila memiliki $p$-value pengujian yang lebih kecil dari pada tingkat signifikansi $(\alpha)$ yang ditetapkan sebesar 5\%. Sedangkan pengujian terakhir dikatakan terpenuhi apabila memiliki p-value pengujian yang lebih besar dari pada tingkat signifikansi $(\alpha)$ sebesar 5\%.

Menurut ReliaSoft Corporation (2015), metode Kaplan-Meier (KM) merupakan salah satu metode non-parametrik dalam analisis survival yang dapat digunakan untuk mengestimasi nilai reliabilitas pada waktu ke $-f, \widehat{R}\left(t_{(f)}\right)$ dari serangkaian data survival baik yang tersensor maupun tidak tersensor. Menurut Kleinbaum dan Klein (2012), metode KM juga dikenal sebagai product limit estimator yaitu peluang bertahan (reliabilitas) sebuah observasi melewati waktu kegagalan sebelumnya $\left(t_{(f-I)}\right)$ dikalikan dengan peluang bertahan melewati waktu $t_{(f)}$ dengan syarat bahwa observasi tersebut telah bertahan minimal sampai waktu $t_{(f)}$. Secara matematis, product limit estimator atau KM dapat ditulis dalam Persamaan (3):

$\widehat{R}\left(t_{(f)}\right)=\widehat{R}\left(t_{(f-1)}\right) x \operatorname{Pr}\left(T>t_{(f)} \mid T \geq\right.$

dengan $\widehat{R}\left(t_{(f-1)}\right)=\prod_{i-1}^{f-1} \operatorname{Pr}\left(T>t_{(i)} \mid T \geq t_{(i)}\right)$

Menurut Kleinbaum dan Klein (2012), log rank (LR) test adalah salah satu metode statistika yang dapat digunakan untuk mengevaluasi apakah kurva nilai reliabilitas Kaplan-Meier dari dua kelompok atau lebih adalah sama (ekuivalen) atau tidak secara statistik. LR test menggunakan perbandingan antara nilai observasi $\left({ }^{O}\right)$ dengan nilai ekspektasi $(E)$ dari setiap kelompok variabel penjelasnya. Kelompok dalam LR test tersebut didefinisikan pada setiap waktu kegagalan yang telah diurutkan dari semua data penelitian yang akan dibandingkan. Secara matematis, LR test untuk perbandingan dua kelompok diberikan pada Persamaan (4). 


$$
L R=\frac{\left(0_{1}-E_{1}\right)^{2}}{\operatorname{Var}\left(0_{1}-E_{1}\right)}=\frac{\left(0_{2}-E_{2}\right)^{2}}{\operatorname{Var}\left(0_{2}-E_{2}\right)}
$$

Di mana $\operatorname{Var}\left(O_{i}-E\right)$ merupakan nilai varians dari selisih antara nilai observasi $(O)$ dengan nilai ekspektasi $(E)$ dari setiap kelompok variabel penjelasnya. Dua kurva KM dikatakan sama (ekuivalen) secara statistik apabila memiliki $p$ value pengujian yang lebih kecil dari $\alpha(0,05)$.

\section{HASIL DAN PEMBAHASAN}

Selama periode 1802-2018 tercatat 219 kejadian tsunami telah terjadi di Indonesia. Sebaran lokasi kejadian tsunami tersebut dapat dilihat pada Gambar 1.

Lokasi kejadian tsunami pada Gambar 1 ditandai dengan belah ketupat berwarna merah yang disertai dengan informasi waktu kejadiannya. Sedangkan garis lurus berwarna hitam merupakan garis khatulistiwa yang melalui Indonesia. Gambar 1 menunjukkan bahwa tsunami pernah terjadi di kedua wilayah, sebelah utara (atas) dan selatan (bawah) garis khatulistiwa dengan frekuensi dan waktu kejadian yang berbeda-beda. Frekuensi dan persentase kejadian tsunami pada masing-masing wilayah relatif terhadap garis khatulistiwa disajikan pada Tabel 1.

Tabel 1. Frekuensi kejadian tsunami di Indonesia tahun $1802-2018$

\begin{tabular}{|c|c|c|c|}
\hline Variabel & Keterangan & $n$ & $\%$ \\
\hline \multirow{3}{*}{$\begin{array}{c}\text { Penjelas } \\
(x)\end{array}$} & Lokasi tsunami & & \\
\hline & $\begin{array}{l}\text { 1: Utara (atas) garis } \\
\text { khatulistiwa }\end{array}$ & 73 & 33,33 \\
\hline & $\begin{array}{l}\text { 2: Selatan (bawah) garis } \\
\text { khatulistiwa }\end{array}$ & 146 & 66,67 \\
\hline
\end{tabular}

Tabel 1 menunjukkan bahwa dalam kurun tahun 1802 hingga 2018, tsunami lebih sering terjadi di wilayah selatan garis khatulistiwa. Dari 219 kejadian tsunami di Indonesia selama periode tersebut, 146 kali $(66,67 \%)$ di antaranya terjadi di wilayah selatan. Data utama yang dianalisis merupakan durasi waktu antar kejadian tsunami yang berurutan pada masing-masing wilayah dalam satuan bulan. Sebagai catatan, untuk menghitung sebuah durasi waktu dibutuhkan dua kejadian tsunami yang saling berurutan. Dengan kata lain, jumlah data durasi waktu antar kejadian tsunami adalah sebanyak $n-1$, di mana $n$ menunjukkan jumlah kejadian tsunami pada masing-masing wilayah. Sehingga data durasi waktu antar kejadian tsunami di wilayah utara berjumlah sebanyak 72 observasi dan di wilayah selatan sebanyak 145 observasi. Visu-

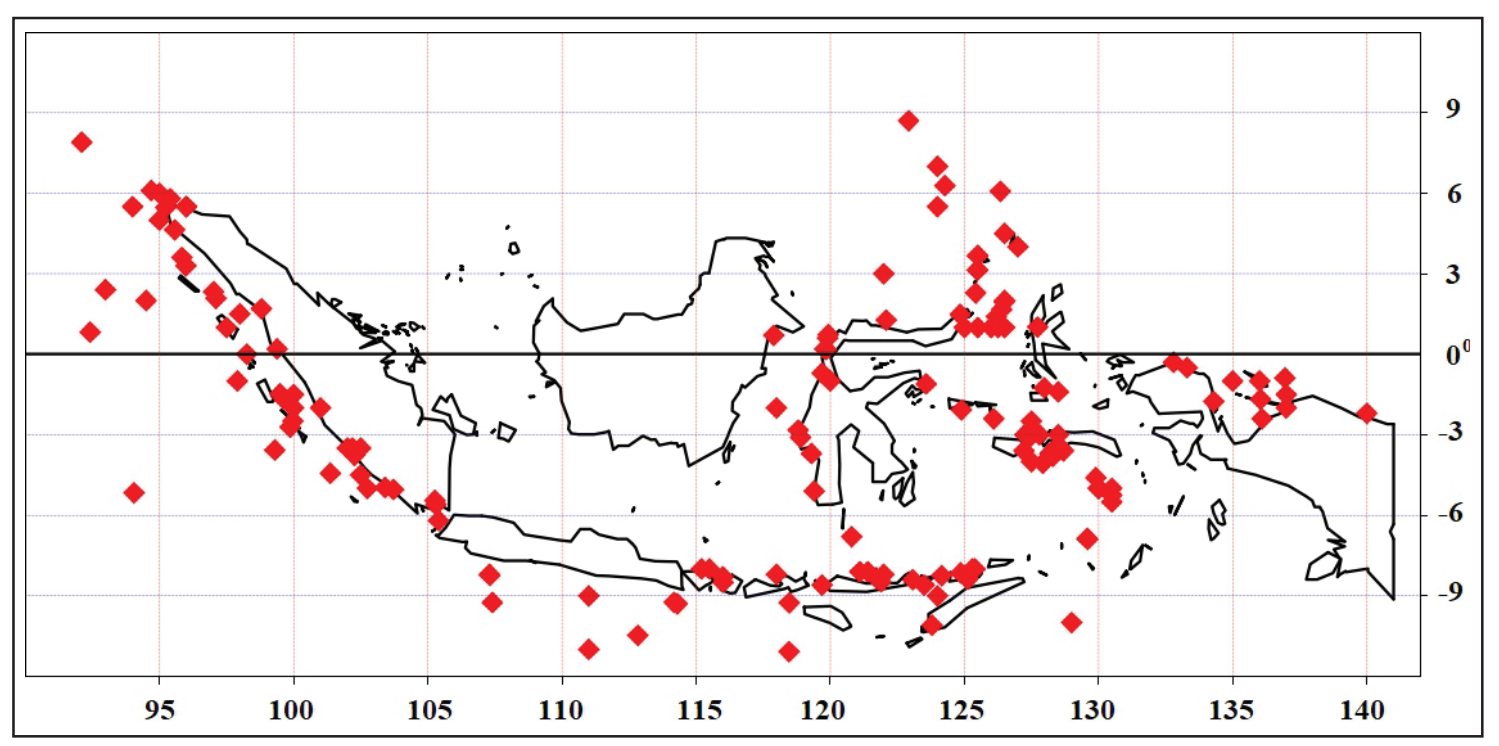

Gambar 1. Sebaran Lokasi Kejadian Tsunami di Indonesia Tahun 1802-2018. 
Perbandingan Nilai Hazard Kejadian Tsunami di Indonesia Berdasarkan Posisi Garis Khatulistiwa (Katalog Tsunami Indonesia 1802 - 2018)

alisasi data durasi waktu antar kejadian tsunami yang saling berurutan untuk masing-masing wilayah ditampilkan pada Gambar 2.

Durasi waktu antar kejadian tsunami yang berurutan di wilayah utara (atas) garis khatulistiwa diberikan pada Gambar 2a dan di wilayah selatan (bawah) garis khatulistiwa diberikan pada Gambar 2b. Durasi waktu terlama pada Gambar 2a berada pada observasi ke-51 atau antara kejadian tsunami pada 9 Mei 1949 di sekitar wilayah Banda Aceh dan 2 April 1964 di wilayah barat laut Aceh. Sedangkan durasi waktu terlama pada Gambar 2b berada pada observasi ke-95 atau antara kejadian tsunami pada 20 Mei 1938 di sekitar Pulau Jawa dan 8 Oktober 1850 di sekitar wilayah NTT. Rangkuman data berupa statistik deskriptif durasi waktu antar kejadian tsunami pada masing-masing wilayah ditampilkan pada Tabel 2.

Tabel 2 menyajikan beberapa statistik deskriptif berupa nilai minimum, maksimum, rata-rata, median dan standar deviasi (SD) data durasi waktu antar kejadian tsunami pada masing-masing wilayah. Tsunami yang terjadi di wilayah utara memiliki rata-rata durasi waktu antar kejadian yang lebih besar dari pada di wilayah selatan dengan perbandingan 30,61 berbanding 18,17 bulan. 50\% kejadian tsunami di wilayah utara terjadi dengan durasi waktu antar kejadian di bawah 14,85 bulan, sedangkan di wilayah selatan berada di bawah 10,67 bulan. Data durasi waktu antar kejadian tsunami di wilayah utara terlihat lebih lebih bervariasi jika dibandingkan kejadian di wilayah selatan yang tergambar melalui statistik standar deviasinya yang lebih besar.

Model Cox $\mathrm{PH}$ dibangun untuk mengevaluasi apakah kejadian tsunami yang terjadi di wilayah utara dan selatan garis khatulistiwa memiliki peluang atau resiko kejadian yang berbeda. Data durasi waktu antar kejadian tsunami merupakan variabel respon model, sedangkan lokasi kejadian relatif terhadap garis khatulistiwa merupakan variabel penjelasnya. Model Cox PH memberikan perbandingan nilai hazard kejadian tsunami di wilayah selatan relatif terhadap wilayah utara garis khatulistiwa. Perbandingan kejadian tsunami di wilayah selatan terhadap wilayah utara dipilih karena wilayah selatan memiliki

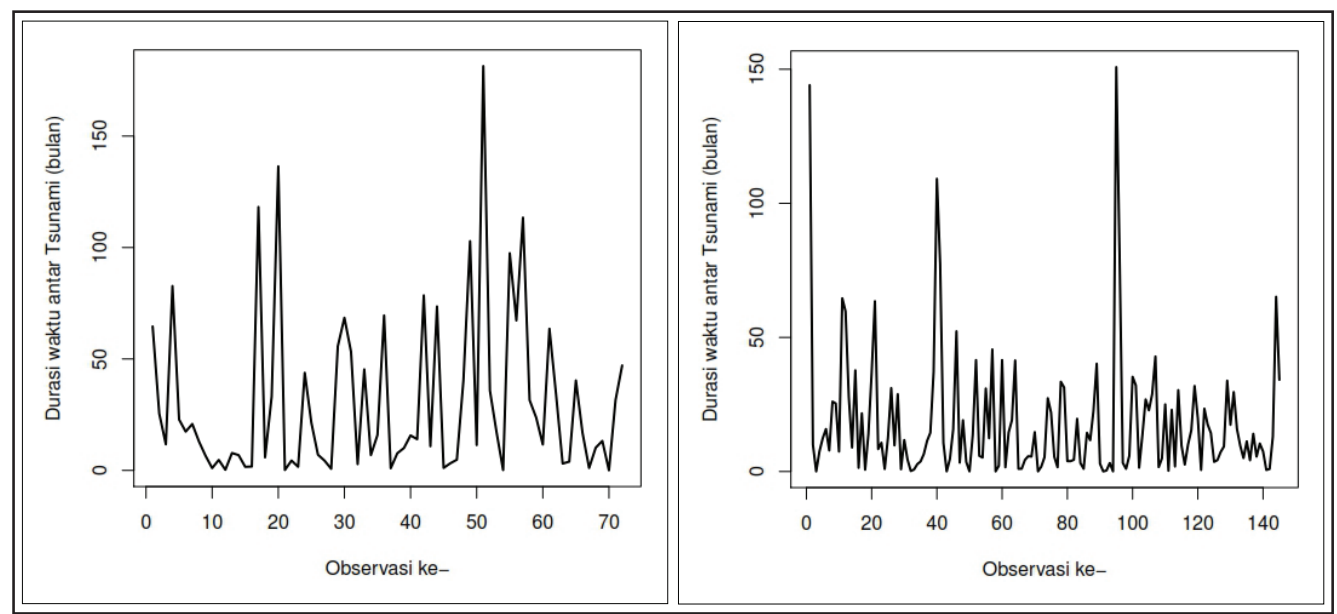

Gambar 1. Sebaran Lokasi Kejadian Tsunami di Indonesia Tahun 1802-2018.

Tabel 2. Statistik deskriptif durasi waktu antarkejadian tsunami (bulan)

\begin{tabular}{clccccc}
\hline Variabel & \multicolumn{1}{c}{ Keterangan } & Min & Mak & Rata-rata & Median & SD \\
\hline Respon & Durasi waktu antarkejadian tsunami & & & & & \\
$T_{1}$ & 1: Utara (atas) garis khatulistiwa & 0,00139 & 181,40 & 30,61 & 14,85 & 37,22 \\
$T_{2}$ & 2: Selatan (bawah) garis khatulistiwa & 0,03333 & 150,80 & 18,17 & 10,67 & 23,90 \\
\hline
\end{tabular}


frekuensi kejadian yang lebih banyak.

Model Cox $P H$ yang baik adalah model yang memenuhi ketiga pengujian yaitu pengujian secara serentak melalui statistik Likelihood Ratio (LR) test, pengujian secara parsial melalui statistik Wald dan pengujian asumsi Proportional Hazard (PH) melalui statistik Chi Square. Tabel 3 menyajikan beberapa statistik penting dalam model Cox $P H$ yaitu nilai beta, hazard rasio, statistik Wald $(Z)$ dan $p$-value dari model Cox $P H$. Selain itu statistik LR test beserta $p$ value pengujiannya juga diberikan pada Tabel 3 .

Pengujian pertama berupa uji serentak dilakukan untuk mengetahui apakah variabel penjelas (lokasi antar kejadian tsunami) secara bersamasama berpengaruh terhadap model Cox $\mathrm{PH}$ yang dibangun. Pengujian melalui statistik LR test menunjukkan bahwa asumsi pengujian serentak telah terpenuhi karena memiliki $p$-value yang lebih kecil dari pada 0,05 dengan nilai statistik LR test sebesar 7,93. Pengujian kedua berupa uji secara parsial melalui statistik Wald (Z) dilakukan untuk mengetahui apakah variabel penjelas secara parsial berpengaruh terhadap model Cox $\mathrm{PH}$. Tabel 3 menunjukkan bahwa pengujian secara parsial terhadap variabel lokasi kejadian tsunami di wilayah selatan memiliki statistik Wald $(Z)$ sebesar 2,76. Nilai tersebut signifikan secara statistik yang ditunjukkan oleh $p$-value pengujian sebesar 0,006 yang berada jauh di bawah nilai $\alpha$ yang ditentukan sebesar 0,05 . Pengujian ketiga berupa asumsi $P H$ ditampilkan pada Tabel 4.
Pengujian asumsi $P H$ dilakukan untuk memastikan bahwa model Cox PH yang dibangun memiliki perbandingan nilai hazard yang proporsional yaitu bernilai konstan dan independen terhadap waktu. Sebuah model dikatakan memenuhi asumsi $P H$ apabila memiliki nilai statistik $C h i-$ square yang tidak signifikan atau memiliki $p$-value pengujian yang lebih besar dari pada $\alpha$ $(0,05)$. Berdasarkan Tabel 4, diketahui bahwa model Cox $P H$ dengan variabel penjelas lokasi kejadian tsunami memiliki statistik Chi-square sebesar 0,346 dengan p-value sebesar 0,556. Dengan demikian, model $C o x P H$ tersebut telah memenuhi asumsi $P H$ atau dengan kata lain perbandingan nilai hazard antar kejadian tsunami di wilayah selatan dan utara bernilai konstan dan independen terhadap waktu.

Setelah memenuhi ketiga pengujian dalam model Cox $\mathrm{PH}$, selanjutnya dilakukan interpretasi model berdasarkan nilai hazard ratio $(H R)$ dari variabel penjelasnya (lokasi kejadian tsunami). Nilai $H R$ dari variabel penjelas lokasi kejadian tsunami pada Tabel 3 adalah sebesar 1,505. Nilai tersebut diperoleh dari nilai Beta (koefisien model $\mathrm{Cox} \mathrm{PH}$ ) yang dieskponsialkan atau secara matematis ditulis sebagai exp (Beta). Nilai $H R$ menunjukkan bahwa kejadian tsunami di wilayah selatan (bawah) garis khatulistiwa cenderung lebih cepat terjadi dengan peningkatan resiko sebesar $(1,505-1)=50,5 \%$ lebih besar dibandingkan dengan kejadian tsunami di wilayah utara (atas) garis khatulistiwa. Ke-

Tabel 3. Model Cox PH durasi waktu antarkejadian tsunami.

\begin{tabular}{clcccc}
\hline \multicolumn{1}{c}{ Keterangan } & Beta & Hazard & Wald & p-value \\
\hline Penjelas $(X)$ & Lokasi kejadian tsunami & & & & - \\
& 1: Utara (atas) garis khatulistiwa $(\mathrm{R})$ & - & - & - & - \\
& 2: Selatan $($ bawah) garis khatulistiwa & 0,409 & 1,505 & 2,76 & 0,006 \\
\hline Likelihood ratio $(L R)$ test $=7,93 ;$-value $=0,005 ;(\mathrm{R}):$ Reference kategori & & & &
\end{tabular}

Tabel 4. Pengujian Asumsi PH durasi waktu antarkejadian tsunami

\begin{tabular}{clccc}
\hline Variabel & \multicolumn{1}{c}{ Keterangan } & Rho & Chi-square & p-value \\
\hline Penjelas $(X)$ & Lokasi kejadian tsunami & & & - \\
& 1: Utara (atas) garis khatulistiwa (R) & - & - & 0,556 \\
\hline & 2: Selatan (bawah) garis khatulistiwa & 0,0402 & 0,346 & 0.56 \\
\hline
\end{tabular}


Perbandingan Nilai Hazard Kejadian Tsunami di Indonesia Berdasarkan Posisi Garis Khatulistiwa (Katalog Tsunami Indonesia 1802 - 2018)

simpulan tersebut juga didukung oleh analisis terhadap nilai reliabilitas kejadian tsunami yang dihitung dengan menggunakan metode non-parametrik Kaplan-Meier. Nilai reliabilitas tersebut menunjukkan besarnya peluang tidak terjadinya tsunami pada waktu tertentu. Semakin besar nilai reliabilitas maka akan semakin kecil peluang kejadian tsunami terjadi. Lokasi kejadian (wilayah utara dan selatan garis khatulistiwa) dengan nilai reliabilitas yang lebih tinggi menunjukkan bahwa kejadian tsunami pada wilayah tersebut cenderung lebih jarang terjadi. Visualisasi nilai reliabilitas kejadian tsunami berdasarkan lokasinya relatif terhadap garis khatulistiwa diberikan pada Gambar 3.

Sumbu $X$ pada Gambar 3 menunjukkan durasi

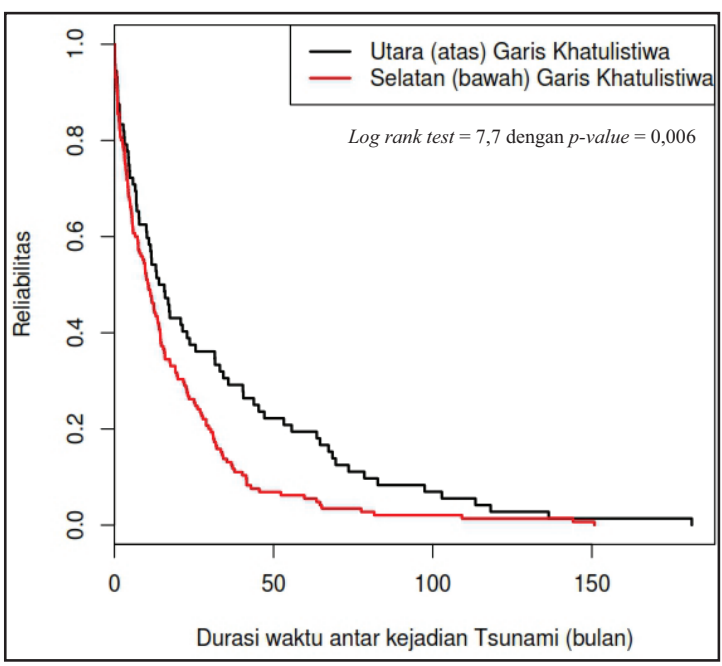

Gambar 3. Estimasi nilai reliabilitas durasi waktu antarkejadian tsunami dengan metode Kaplan-Meier.

waktu antar kejadian tsunami dan sumbu $Y$ menunjukkan besarnya nilai reliabilitas yang bersesuaian dengan durasi waktu kejadian tersebut. Nilai reliabilitas durasi waktu antar kejadian tsunami di wilayah utara diberikan oleh garis berwarna hitam, sedangkan untuk durasi waktu antar kejadian di wilayah selatan diberikan oleh garis berwarna merah. Panjangnya kurva nilai reliabilitas durasi waktu kejadian tsunami antar lokasi terlihat berbeda. Hal ini dikarenakan adanya perbedaan durasi waktu antar kejadian tsunami maksimal pada kedua lokasi. Berdasarkan Tabel 2, diketahui bahwa durasi waktu maksimal antar kejadian tsunami di masing-masing wilayah utara dan selatan adalah selama 181,40 dan 150,80 bulan. Secara umum, Gambar 3 menunjukkan bahwa nilai reliabilitas kejadian tsunami di wilayah utara (garis hitam) terlihat lebih besar dari pada wilayah selatan (garis merah). Hal ini menunjukkan bahwa kejadian tsunami di wilayah utara cenderung lebih jarang terjadi dibandingkan dengan wilayah selatan garis khatulistiwa.

Perbedaan nilai reliabilitas antara wilayah utara dan selatan tersebut bernilai signifikan secara statistik yang ditunjukkan oleh nilai $L R$ test sebesar 7,7 dengan $p$-value pengujian yang signifikan sebesar 0,006. Dengan demikian, penelitian ini menyimpulkan bahwa lokasi kejadian tsunami yang dibedakan menjadi wilayah utara dan selatan garis khatulistiwa turut memengaruhi durasi waktu antar kejadian tsunami di Indonesia.

Kejadian tsunami sangat berkaitan erat dengan tsunamigenik. Menurut Yudhicara dan Budiono (2008), tsunamigenik adalah suatu kejadian di alam yang berpotensi menyebabkan tsunami akibat terganggunya air laut oleh kegiatan gunungapi, gempa bumi, longsoran pantai dan bawah laut, dan sebab-sebab lainnya. Dari 7 wilayah rawan bencana gempa bumi di Indonesia yang dipetakan oleh Galih dan Hadayani (2007) dengan metode fraktal, 5 di antaranya berada di wilayah selatan garis khatulistiwa yaitu wilayah I (Jawa), IV (Sulawesi), V (Papua), VI (Bali, Lombok, NTT dan sekitarnya) dan VII (Maluku, Banda, Halmahera dan sekitarnya). Hal ini menunjukkan bahwa wilayah selatan berpeluang mengalami lebih banyak kejadian gempa bumi yang juga berpotensi menyebabkan tsunami dari pada wilayah utara. Selanjutnya jika dikaitkan dengan keberadaan gunungapi, lebih dari $75 \%$ gunungapi tipe A yaitu gunungapi yang tercatat pernah meletus sejak tahun 1600 berada di wilayah selatan garis khatulistiwa (Zaennudin, 2010). Lebih rinci, penelitian Yudhicara dan Budiono (2008) di sekitar wilayah 
Selat Sunda menunjukkan bahwa beberapa fenomena geologi seperti gempa bumi (tahun 1722, 1852, dan 1958), erupsi gunungapi bawah laut Krakatau (tahun 416, 1883, dan 1928), dan penyebab lainnya seperti kegagalan lahan berupa longsoran baik yang terjadi di kawasan pantai maupun dasar laut (tahun 1851, 1883, dan 1889) telah menyebabkan wilayah tersebut sering mengalami kejadian tsunami. Secara umum, ketiga penelitian tersebut dapat membantu menjelaskan mengapa kejadian tsunami di wilayah selatan cenderung lebih banyak dan lebih sering terjadi dari pada wilayah utara garis khatulistiwa.

Penelitian lebih lanjut diperlukan untuk menjelaskan kaitan antara zona subduksi dengan garis khatulistiwa. Hal ini diperlukan mengingat kejadian tsunamigenik sangat berkaitan erat dengan keberadaan zona subduksi akibat pertemuan lempeng tektonik dunia. Gempa bumi, aktivitas vulkanik, pembentukan gunung dan palung samudera umumnya terjadi di zona pertemuan lempeng tektonik dengan panjang mulai dari beberapa kilometer hingga dapat mencapai ratusan kilometer (GNS Science, 2020). Sekitar 82,3\% dari seluruh tsunami yang terjadi di Samudera Pasifik dalam dua ribu tahun terakhir disebabkan oleh gempa bumi (Bryant, 2014). Menurut Romano (2009), tsunamigenik terutama yang terkait gempa bumi ditentukan oleh beberapa faktor seperti mekanisme gempabumi, kedalaman retakan yang terjadi dan distribusi slip di sepanjang zona patahan, serta proses mekanik lainnya yang terjadi di zona sumber gempa bumi. Anwar (2019) menunjukkan bahwa gempa bumi berkekuatan besar $(M>5,5)$ dapat terjadi tanpa didahului oleh gempa bumi yang lebih kecil. Meskipun dengan peluang yang cukup kecil, gempa bumi dengan magnitudo $>7,6$ dapat terjadi sebelum terjadinya gempa bumi dengan magnitudo antara 5,0 hingga 7,6. Menurut USGS (1999), gempa bumi dengan kekuatan 7,6 hingga 7,8 telah berpotensi menyebabkan tsunami yang merusak, terutama di daerah yang dekat dengan pusat gempa bumi. Sejalan dengan hal tersebut, sekitar dua pertiga atau $67 \%$ dari kejadian tsu- nami yang bersifat merusak di wilayah Samudera Pasifik umumnya disebabkan oleh gempa bumi dengan magnitudo 7,5 atau lebih (Bryant, 2014). Disis lain, gempa bumi yang terjadi terutama yang berkekuatan besar juga berpengaruh terhadap rotasi bumi, mengurangi panjang durasi waktu hari, merubah sedikit bentuk bumi dan menggeser posisi kutub utara beberapa centimeter ke arah timur (NASA, 2005). Perubahanperubahan tersebut secara langsung maupun tidak langsung juga akan berpengaruh terhadap garis tengah (khatulistiwa) bumi yang paralel terhadap poros rotasi bumi. Adanya hubungan timbal balik dengan mekanisme yang kompleks tersebut membutuhkan investigasi yang lebih mendalam untuk memahami hubungan antara garis khatulistiwa dengan zona subduksi dan kejadian tsunamigenik di Indonesia khususnya dan di dunia pada umumnya.

Selain penelitian terkait hubungan antara keberadaan zona subduksi dan kejadian tsunamigenik dengan garis khatulistiwa, analisis pada lapisan wilayah (layer) yang lebih sempit mulai dari yang terdekat hingga terjauh dari garis khatulistiwa secara horizontal juga akan membantu memberikan penjelasan lebih lanjut apakah garis khatulistiwa memiliki pengaruh terhadap kejadian tsunami di Indonesia. Hal ini dapat dilakukan dengan memisahkan data kejadian tsunami berdasarkan derajat latitudenya. Perbandingan analisis dapat dilakukan antar layer pada kedua belahan bumi utara dan selatan untuk melihat apakah perbedaan $H R$ kejadian tsunami di kedua wilayah konsisten terjadi pada semua layer tersebut.

Keterbatasan penelitian merupakan salah satu hal penting yang harus disampaikan. Besarnya nilai $H R$ dalam penelitian ini dihitung hanya dengan mempertimbangkan faktor lokasi kejadiannya (utara dan selatan garis khatulistiwa), faktor lain mungkin turut mempengaruhi nilai $H R$ kejadian tsunami di Indonesia. Kelengkapan catatan kejadian tsunami khususnya yang berkaitan dengan waktu (tanggal, bulan dan tahun kejadian) merupakan isu penting lainnya. 
Perbandingan Nilai Hazard Kejadian Tsunami di Indonesia Berdasarkan Posisi Garis Khatulistiwa (Katalog Tsunami Indonesia 1802 - 2018)

Waktu terjadinya kejadian tsunami sebelum tahun 1800 tidak tercatat secara lengkap terutama tanggal dan bulan kejadiannya. Sehingga durasi waktu antar kejadian tsunami yang berurutan sebelum 1800 tidak dapat dihitung secara tepat. Beberapa kejadian tsunami juga tidak dilengkapi dengan lokasi koordinat kejadiannya, sehingga visualisasi lokasi melalui peta agak sulit dilakukan khususnya untuk kejadian tsunami tersebut. Sebagian besar tsunami yang tidak tercatat lokasi koordinat kejadiannya tersebut terjadi sebelum tahun 1900. Hal ini mungkin disebabkan karena belum berkembangnya teknologi sistem informasi peringatan dini tsunami pada waktu itu. Terakhir, hasil analisis yang diperoleh pada penelitian ini hanya didasarkan pada katalog tsunami BMKG, kombinasi dengan data tsunami dari katalog lainnya akan meningkatkan tingkat akurasi hasil penelitian.

\section{KESIMPULAN}

Dari penelitian ini dapat disimpulkan bahwa kejadian tsunami di wilayah selatan (bawah) garis khatulistiwa cenderung lebih sering terjadi dibandingkan dengan wilayah utara. Model Cox PH menunjukkan bahwa tsunami di wilayah selatan cenderung $50,5 \%$ lebih cepat terjadi. Hal ini disebabkan karena wilayah selatan berpotensi lebih besar akan terjadinya tsunamigenik termasuk gempa bumi, erupsi gunungapi dan penyebab lainnya dari pada wilayah utara.

\section{UCAPAN TERIMA KASIH}

Ucapan terima kasih kepada Badan Meteorologi, Klimatologi dan Geofisika (BMKG) atas katalog kejadian Tsunami di Indonesia tahun 416 - 2017.

\section{DAFTAR PUSTAKA}

Anwar, S., 2019. Mengukur Peluang Kejadian Gempa Bumi dengan Lompatan Magnitudo di Wilayah Pulau Sumatera. Jurnal Lingkungan dan Bencana Geologi 10(3): 159-170. https://doi.org/10.34126/JLBG.V10I3.263
BMKG., 2018. Katalog Tsunami Indonesia Tahun 416-2017 (First edition). Badan Meteorologi Klimatologi dan Geofisika, Jakarta.

Borrero, J. C., Sieh, K., Chlieh, M., dan Synolakis, C. E., 2006. Tsunami inundation modeling for western Sumatra. In Proceedings of the National Academy of Sciences of the United States of America 103: 1967319677. National Academy of Sciences, Washington DC. https://doi.org/10.1073/ pnas.0604069103

Bryant, E., 2014. Tsunami: The Underrated Hazard (Third Edition). Springer, New York.

Fradin, J. B., dan Fradin, D. B., 2008. Witness to Disaster: Tsunamis. National Geographic Society, Washington DC.

GNS Science., 2020. Tectonic Plates and Plate Boundaries. https://www.gns.cri.nz/Home/ Learning/Science-Topics/Earthquakes/ Earthquakes-at-a-Plate-Boundary/TectonicPlates-and-Plate-Boundaries, diunduh 21 Desember 2020

Hartanto, D., 2016. Sumber Tsunami Gempa Bumi Iquique, Chili 2014 Menggunakan Metode Back Propagation Tsunami Travel Time (TTT). Jurnal Meteorologi dan Geofisika 17(1): 9-13. https://doi.org/10.31172/ JMG.V17I1.372

Ito, T., Gunawan, E., Kimata, F., Tabei, T., Meilano, I., Agustan, ... Sugiyanto, D., 2016. Co-seismic offsets due to two earthquakes (Mw 6.1) along the Sumatran fault system derived from GNSS measurements. Earth, Planets and Space 68(57): 1-8. https://doi. org/10.1186/s40623-016-0427-z

Jatnika, J., Nugraha, A. D., dan Wandono., 2016. Relokasi Sumber Gempa di Daerah Sumatera Bagian Utara Menggunakan Hasil Inversi Simultan Relokasi dan Kecepatan Gelombang P Tiga Dimensi. Jurnal Meteorologi dan Geofisika 16(2): 113-121. https:// doi.org/10.31172/JMG.V16I2.274

Kleinbaum, D. G., dan Klein, M., 2012. Survival analysis: a self-learning text (Third edition). Springer Science Business Media, Inc., New York. 
Lay, T., Kanamori, H., Ammon, C. J., Nettles, M., Ward, S. N., Aster, R. C., ... Sipkin, S., 2005. The great Sumatra-Andaman earthquake of 26 December 2004. Science 308(5725): 1127-1133. https://doi. org/10.1126/science. 1112250

Løvholt, F., Bungum, H., Harbitz, C. B., Glimsdal, S., Lindholm, C. D., dan Pedersen, G., 2006. Earthquake related tsunami hazard along the western coast of Thailand. Natural Hazards and Earth System Science 6(6): 979-997. https://doi.org/10.5194/ nhess-6-979-2006

Lusiani, E., Anwar, S., dan Nugraha, M. F., 2019. Penentuan Tingkat Seismisitas Wilayah Propinsi Aceh Dengan Metode Gutenberg Richter (Nilai A dan Nilai B). Jurnal Meteorologi dan Geofisika 19(2): 71-79. https://doi.org/10.31172/jmg. v19i2.536

NASA., 2005. NASA Details Earthquake Effects on the Earth. https://www.jpl.nasa.gov/ news/news.php?release $=2005-009$, diunduh 21 Desember 2020.

Natawidjaja, D. H., 2007. Gempabumi dan Tsunami di Sumatra dan Upaya Untuk Mengembangkan Lingkungan Hidup Yang Aman Dari Bencana Alam. LIPI, Jakarta.

National Geographic., 2011. Equator. https:// www.nationalgeographic.org/encyclopedia/ equator/, diunduh 10 Januari 2020.

National Geographic., 2012. Latitude. https:// www.nationalgeographic.org/encyclopedia/ latitude/, diunduh 10 Januari 2020.

Nugraha, J., Pasau, G., Sunardi, B., dan Widiyantoro, S., 2014. Seismic Hazard Analysis and Isoseismal for Java-Bali-NTB (Analisis Hazard Gempa dan Isoseismal untuk Wilayah Jawa-Bali-NTB). Jurnal Meteorologi dan Geofisika 15(1): 1-11. https://doi. org/10.31172/jmg.v15i1.168

Oktiari, D., dan Manurung, S., 2010. Model Geospasial Potensi Kerentanan Tsunami Kota Padang. Jurnal Meteorologi dan Geofisika 11(2): 140-146. https://doi. org/10.31172/JMG.V11I2.73
Paris, R., Cachão, M., Fournier, J., dan Voldoire, O., 2010. Nannoliths abundance and distribution in tsunami deposits: example from the December 26, 2004 tsunami in Lhok Nga (northwest Sumatra, Indonesia). Géomorphologie : Relief, Processus, Environnement 16(1): 109-118. https://doi.org/10.4000/ geomorphologie.7865

Paris, R., Lavigne, F., Wassmer, P., dan Sartohadi, J., 2007. Coastal sedimentation associated with the December 26, 2004 tsunami in Lhok Nga, west Banda Aceh (Sumatra, Indonesia). Marine Geology 238(14): 93-106. https:// doi.org/10.1016/j.margeo.2006.12.009

ReliaSoft Corporation., 2015. Life Data Analysis Reference. ReliaSoft Corporation, Arizona.

Restuning Galih, D., dan Hadayani, L., 2007. Pemetaan Pola Terjadinya Gempa Bumi di Indonesia dengan Metode Fraktal. Jurnal RISET Geologi dan Pertambangan 17(2): 51-56. https://doi.org/10.14203/risetgeo$\operatorname{tam} 2007 . v 17.174$

Rifai, L. D., dan Pudja, I. P., 2010. Studi Awal Hubungan Gempa Laut dan Gempa Darat Sumatera dan Sekitarnya. Jurnal Meteorologi dan Geofisika 11(2): 147-153. https:// doi.org/10.31172/JMG.V11I2.74

Romano, F., 2009. The rupture process of recent tsunamigenic earthquakes by geophysical data inversion. Disertasi. Università Degli Studi Di Bologna.

Sanjaya, J., 2018. Tsunami Disaster Preparedness Simulation on North Buton Regency. Journal of the Civil Engineering Forum 4(2): 179-190.

Satake, K., dan Atwater, B. F., 2007. Long-Term Perspectives on Giant Earthquakes and Tsunamis at Subduction Zones. Annual Review of Earth and Planetary Sciences 35(1): 349-374. https://doi.org/10.1146/annurev. earth.35.031306.140302

Setyonegoro, W., 2011. Tsunami Numerical Simulation Applied to Tsunami Early Warning System Along Sumatra Region. Jurnal Meteorologi dan Geofisika 12(1): 21-32. https://doi.org/10.31172/JMG.V12I1.85 
Perbandingan Nilai Hazard Kejadian Tsunami di Indonesia Berdasarkan Posisi Garis Khatulistiwa (Katalog Tsunami Indonesia 1802 - 2018)

Stein, S., dan Okal, E. A., 2005. Speed and size of the Sumatra earthquake. Nature 434 (7033): 581-582. https://doi.org/10.1038/434581a

Subarya, C., Chlieh, M., Prawirodirdjo, L., Avouac, J.-P., Bock, Y., Sieh, K., ... McCaffrey, R., 2006. Plate-boundary deformation associated with the great Sumatra-Andaman earthquake. Nature 440(7080): 46-51. https://doi.org/10.1038/nature04522

Triatmodjo, B., 1999. Teknik Pantai. Beta Offset, Yogyakarta.

USGS., 1999. What is it about an earthquake that causes a tsunami? https://www.usgs. gov/faqs/what-it-about-earthquake-causesa-tsunami?qt-news_science_products $=0 \#$ qtnews_science_products, diunduh 9 Januari 2020.

Wahyu, R. O., Djamaluddin, R., Mamuaya, G. E., Yatimantoro, T., dan Priyobudi, P., 2018. Pemodelan Inundasi Tsunami di Sepanjang Pesisir Manado Akibat Gempabumi M8,5 di Zona Subduksi Sulawesi Utara. Jurnal Meteorologi dan Geofisika 19(1): 13-18. https://doi.org/10.31172/jmg.v19i1.448
Wang, X., dan Liu, P. L.-F., 2007. Numerical Simulations of the 2004 Indian Ocean Tsunamis - Coastal Effects. Journal of Earthquake and Tsunami 01(03): 273-297. https://doi.org/10.1142/s179343110700016x

Younger, J. S., Mattholie, R. A., dan Setiawan, B., 2009. Site investigation for disaster reconstruction in Aceh, Sumatra. Proceedings of the Institution of Civil Engineers - Geotechnical Engineering 162(1): 41-47. https:// doi.org/10.1680/geng.2009.162.1.41

Yudhicara, Y., dan Budiono, K., 2008. Tsunamigenik di Selat Sunda: Kajian terhadap katalog Tsunami Soloviev. Jurnal Geologi Indonesia 3(4): 241-251. http://dx.doi. org/10.17014/ijog.vol3no4.20086

Zacks, S., 1992. Introduction to Reliability Analysis : Probability Models and Statistical Methods. Springer, New York.

Zaennudin, A., 2010. The characteristic of eruption of Indonesian active volcanoes in the last four decades. Jurnal Lingkungan dan Bencana Geologi 1(2): 113-129. http:// dx.doi.org/10.34126/jlbg.v1i2.10 